\title{
Legal System Of Tax Income And Tariff Revenue In The Natural Resources And The Mining Sector In Nigeria: Obstacles And Challenges In Collecting Taxes And Duties, Parliamentary And Judicial Control
}

\author{
Ninette Nyalyen Ninyio ${ }^{1}$
}

\begin{abstract}
Nigeria is endowed with a wide variety of economic minerals which are spread across all the geopolitical zones of the nation. The ownership, management and control of natural resources in Nigeria is enshrined in the Constitution, and recognized by the United Nations Organization (UN). In 1962, the General Assembly of the United Nations deliberated and adopted Resolution 1803, (xvii) titled "Permanent Sovereignty over Natural Resources". This resolution changed the ownership structure of natural resources from investor ownership to State control of natural resources. The Federal Government of Nigeria, being the owner of natural resources in Nigeria, by virtue of being a member of the United Nations, and a signatory to the treaty which has been transmuted into municipal law, formulates policies which guarantee it receives some compensation for allowing the extraction of these resources. Chief among these policies is the fiscal policy, which is aimed at ensuring that government acquires benefits from the mining of these resources, or simply referred to as taxation or the levying of tax. The legal regime of these fiscal policies is what this presentation seeks to examine, and shall be considered against the backdrop of the obstacles and challenges that mitigate the optimal realization of benefits to be accrued in its implementation, which may be parliamentary or judicial in nature. In doing this, the various extant tax laws on are examined. For clarity, Nigeria operates a presidential system of government and not a parliamentary one, and any reference to parliamentary here strictly means the legislative segment of the government.
\end{abstract}

\section{A. Introduction}

The history of mining in Nigeria can be traced back to the period prior to the discovery of oil in 1956, and the increase of oil exploration and production in the 1970's. Nigeria produced a variety of minerals such as tin and columbite as well as industrial minerals such as limestone. Production in Nigeria was then a significant contributor to the country's GDP.

1 Ninette Nyalyen Ninyio, Company Secretary at Kingfem Group of Companies Ltd, Abuja, Nigeria and Legal Practitioner at Kolawole Olowookere and Company, Abuja, Nigeria; ninyioninette@gmai 1.com, +2347034221380 . 
Organized mining began in 1903 when the Mineral Survey of the Northern Protectorates was created by the British colonial government. A year later, the Mineral Survey of the Southern Protectorates was founded. By the 1940s, Nigeria was a major producer of tin, columbite, and coal. ${ }^{2}$

In the 1900s up until 1970s the mining sector was a major revenue source for Nigeria. Crude oil production and the OPEC oil shock which happened in the 1970s affected the hitherto encouraging investments in Nigeria's mining sector by distracting investment flow into mining as well as some other sectors of the economy. This is more so as crude oil production was seen as a bigger revenue source. This situation plummeted solid mineral contribution to Nigeria's gross domestic product (GDP) from the mid-1970s up until the 2007 reforms. ${ }^{3}$

Nigeria has proven deposits of natural resources - both solid minerals and hydrocarbons, with large reserves of natural gas, petroleum, tin, iron, ore, gold, limestone, lead, zinc, sapphire, tantalite, tourmaline, etc. The country has about 34 solid minerals in commercial quantity in about 450 locations across the country which includes bitumen, gold, coal, iron ore, lead, zinc, limestone, barites, etc ${ }^{4}$.

The major law governing mining in the country is the Minerals and Mining Act of 2007. The Act vested the regulation of the mining sector under the Minister for Solid Minerals Development who has authority on behalf of the Federal Government of Nigeria to carry out the acts specified under the Act. ${ }^{5}$

The Act defines Minerals (or Mineral Resources) in the following words:

"Any substance whether in solid, liquid or gaseous form occurring in or on the earth, formed by or subjected to geological processes including occurrences or deposits of rocks, coal, coal bed gases, bituminous shales, tar, sands, any substances that may be extracted from coal, shale or tar sands, mineral water, and mineral components in tailings and waste piles, but with the exclusion of petroleum and waters without mineral content." 6

The Act defines mining as follows:

To intentionally mine minerals, and includes any operations directly or indirectly necessary therefore or incidental thereto, including such processing of minerals as may be required to produce a first saleable product.... ${ }^{7}$

2 Dr. Perisuo Dema, Taxation Of Natural Resources: Legal Framework Choices, https://www.ibfd.org >pdf accessed on April 4, 2019 (p. 8).

3 Dema, p.10.

4 Prof. Lar Uriah, Geology and Mineral Resources of Nigeria and Their Uses www.researchgate.net/ publication/322963731_> accessed on 01/05/2019.

5 Section 4 Minerals and Mining Act, 2007.

6 Section 164 Minerals and Mining Act, 2007.

7 Section 164 Minerals and Mining Act, 2007. 
The Supreme Court's decision in C.G.G (NIG.) Ltd. v. Ogu ${ }^{8}$, defines mining as having "the same meaning assigned to it in the Minerals Act and shall include the use of explosive works authorized under the Petroleum Act".

\section{B. Legal Framework governing Natural Resources and Mining in Nigeria.}

The phrase Legal framework includes all rules, laws, policies, and regulations which govern natural resources and mining in Nigeria. The legal framework which governs Natural resources and mining in Nigeria is rested on 3 major laws thus; The 1999 Constitution, The Minerals and Mining Act, 2007, and the Petroleum Act, Laws of Federation of Nigeria 2004. The Petroleum Act is worthy of mention, in view of the fact that Petroleum is Nigeria's prime and most explored Natural resource, which constitutes a bulk sector of Nigeria's internally generated revenue. In furtherance of the exercise of the power conferred on him under the Act, the then Hon. Minister of Mines and Steel Development, Arc. Musa Mohammed Sada, on 24th May, 2011, signed the Minerals and Mining regulations, 2011. Each of these laws shall be briefly reviewed.

\section{The 1999 Constitution (As amended).}

The Constitution is the supreme and apex law of the land, which is the foundation upon which every other law is founded or built. Its supremacy was captured wherein it was provided for that if any other law is inconsistent with the provisions of the Constitution, the Constitution shall prevail and that other law shall to the extent of its inconsistency be void. ${ }^{9}$

This fact has received several judicial blessings and pronouncements as being the organic law from which all other laws flow and derive their validity, and which prescribes the rights, duties, powers and responsibilities of all the organs derivable from it. ${ }^{10}$

Nigeria's ownership of all mineral resources in the nation stems from the Federal Government of Nigeria's encapsulation of the United Nations Resolution 1803 (xvii) 1962 on Permanent Sovereignty over natural resources, into the Nigerian Constitution. The Constitution of Federal Republic of Nigeria provides:

"Notwithstanding the foregoing provision of this section, the entire property in and control of all mineral, oils and natural gas in, under or upon any land in Nigeria or in under or upon the territorial waters and exclusive economic zone of Nigeria shall vest in the government of the Federation, and shall be managed in such manner as may be prescribed by the National Assembly"11

8 [2005] 8 N.W.L.R (Pt. 927) 366.

9 Section1 (1) 1999 Constitution.

10 Famfa Oil Ltd. v. A-G Federation \& NNPC [2003] 18 N.W.L.R (Pt. 852) 453 SC.

11 Section 44(3) Constitution of the Federal Republic of Nigeria 1999. 
A cursory interpretation of the above reveals that exclusive ownership of all natural resources lies within the exclusive preserve of the Federal government and can only be legislated upon by the National Assembly. In terms of jurisdiction for dispute resolution, Section 251 (1n) identifies the Federal court as the only court to handle civil court cases on mines and minerals.

\section{Nigerian Minerals and Mining Act 2007.}

This is an act of the National Assembly made pursuant to their powers derived from the Constitution to make regulations for the control of natural and mineral resources in Nigeria. It came into law in 2007, and repealed the minerals and Mining Act of 1999.

The Nigerian Minerals and Mining Act, $2007^{12}$ stated thus:

The entire property in and control of all mineral Resources in, under or upon any land in Nigeria, its contiguous continental shelf and all rivers, streams and water courses throughout Nigeria, and area covered by its territorial waters, or constituency and the Exclusive Economic Zone is and shall be vested in the Government of the Federation for and on behalf of the people of Nigeria.

The act made for private participation in the ownership of Mineral Rights by the authority of the Federal Government wherein it provided that the property in mineral resources shall pass from the Government to the person by whom the mineral resources are lawfully won, upon their recovery in accordance with the Act. ${ }^{13}$ Such participation is through obtaining of relevant licenses grantable under the Act, at the Mining Cadastre Office. ${ }^{14}$ The Act also empowers the Federal Government to acquire any private land upon which minerals have been discovered in commercial quantity in accordance with the provisions of the Land Use Act. ${ }^{15}$ The administration of the sector is vested in the Ministry of Mines and Steel Development, headed by the Minister for Solid Minerals Development who has the general responsibility for the proper administration of the Act as relates to exploitation of Nigeria's mineral resources. ${ }^{16}$

The Ministry of Mines and Steel Development has various technical departments established for the free flowing and seamless administration of mining in Nigeria. They are thus:

- The Mines Inspectorate Department

This has the overall responsibility for operations in exploration, evaluation as well as mine development and production, and collection of revenues

12 Section 1(1).

13 Sections 1(3) and 147 of the Mineral and Mining Act, 2007 Cap 20, Laws of the federation of Nigeria 2004.

14 Ibid, Section 147.

15 Ibid, Sections 1(2).

16 Ibid, Sections 3. 
- The Mines Environmental and Compliance Department This department is responsible for ensuring that companies adopt and maintains procedures that are environmentally friendly in their operations.

- Artisanal and Small-scale Mining Department (ASM)

The ASM is a department in MMSD with the responsibility to organize, support and assist small scale mining operations.

- Mining Cadastral Office (MCO): ${ }^{17}$

This is an autonomous institution responsible for the administration of mineral titles, interaction with investors when granting and processing mineral titles and maintenance of cadastral atlas and title registers.

\section{Petroleum Act 1969.}

This act came into force in 1969 for the regulation of petroleum and its use in Nigeria.

As regards the control of petroleum in Nigeria, the Act $^{18}$ provides that:

"The entire ownership and control of all petroleum under or upon any lands to which the section applies shall vest in the State". The Act also granted the Minister for Petroleum the powers to make any regulations necessary for an effective administration of the Act.

\section{Minerals and Mining Regulations}

Another important legislative framework in the mining sector is the Minerals and Mining Regulations, which came into force in 2011, under the auspices of the then Minister of Mines and Steel Development, Arc. Musa Mohammed Sada, in furtherance of the exercise of the power conferred on him under the Act to make regulations in respect of any matter required to be prescribed by the regulation, and generally for giving full effect to the provisions of the Act. ${ }^{19}$

\section{Legal framework governing tax income and tariff revenue of natural resources and mining in Nigeria.}

\section{Taxation}

Taxation is a monetary charge imposed by the government on persons, entities, or property to yield public revenue. Broadly speaking, the term embraces all governmental impositions on occupation and enjoyment of the people and includes duties, imports and exercises. It

17 Ibid, 147.

18 Section 1(1) Petroleum Act, 1969, Laws of Federation of Nigeria 2004.

19 Section 21, Mineral and Mining Act, 2007 Cap 20, Laws of the federation of Nigeria 2004. 
can also be defined as "a charge, usually monetary, imposed by the government on persons, entities, transactions, or property to yield public revenue..$^{20}$ Although a tax is often thought of as being pecuniary in nature, it is not necessarily payable in money. ${ }^{21}$

Taxes are the enforced proportional contributions from persons and property levied by the state by virtue of its sovereignty for the support of government and public needs. ${ }^{22}$ Thus it is sovereignty that confers the power to levy tax by the government of a state.

The Government is obliged to provide certain infrastructure to its citizenry. One of the mode of raising capital for such projects include levying of tax. The essence of such tax is to enable the government fund public corporations which provide infrastructure and services to the people.

There is now, a long overdue realization and recognition of taxation as a veritable instrument for National development... aside from being a major source of revenue for government to provide goods and services needed by the people, tax policies can and do stimulate economic growth and job creation through its impact on investment and capital formation in the economy. ${ }^{23}$ Due to the importance of tax, and its place in the economy, every nation ought to have an efficient system of taxation. A good tax system should have some basic characteristic. ${ }^{24}$ These characteristics, as opined by Adams Smith in his book "The Wealth of Nations", ${ }^{25}$ referred to them as Canons of Taxation. They are equity, certainty, convenience, and economy.

Taxation is therefore a veritable tool for the exercise of control over natural resources with a view to discouraging rapid depletion of those resources by the Investors with the finance and expertise, and providing necessary infrastructures and services for the welfare of its citizens. ${ }^{26}$

The Nigerian tax system is a tripartite structure which comprises of Tax policy, Tax legislation, and Tax administration. The tax policy forms the basis for tax laws while the tax administration speaks to the implementation of the tax laws.

\section{Taxation of Natural Resources and Minerals}

The economic importance and essence of natural resources, and its mining and exploration to Nigeria cannot be over emphasized. The government has imposed statutory obligations

20 Garner, B. A., Black's Law Dictionary, Deluxe Ninth Edition (2009), p. 1595.

21 Blacks law dictionary, $7^{\text {th }}$ edition, 1469.

22 Corley, T.M. The Law of Taxation 4th ed. P. 61.

23 Lilian Hart, Issues and challenges with the Nigerian taxation system- Chemiron v LIRS revisited, https://proshareng.com/news $>$ (last accessed 02/05/2019).

24 Lawal, p. 9.

25 Adam, S, Wealth of Nations, (New York: 2003), p.1042.

26 Prof. Richard Idubor, Prof Dominic Asada and Olong Matthew Adefi, Appraising taxation and the Nigerian Oil Industry, Journal of Law Policy and Globalization, Volume 37, 2015, 188 www.iiste. org April 4,2019, p. 192. 
on entities who have ventured into the exploration of these resources which include taxes, include duties, and excises. The nature of these obligations is what the searchlight is beamed on hereunder.

The Petroleum Act which is the fundamental framework guiding petroleum exploration (the major source of revenue generation) in Nigeria allows for the participation on individuals, and entities in the commercial exploration of petroleum Natural resources, and as such makes them subject to taxation.

The Mining Act also allows the participation of companies and individuals, as well as co-operative societies, in the mining sector. This opens the sector to various forms of tax, depending on whether the entity is an individual or corporation.

It is important to note here that regulation of tax in the Nigerian natural resources and mining sphere, falls within the ambit of five principal legislations among others, depending on the nature and scope of operation of such companies. These are namely:

- Petroleum Profit Tax Act Cap p 13 LFN 2004

- Companies Income tax Act LFN 2004

- Personal Income Tax Act LFN 2004

- Education Tax Act

- Value Added Tax Act LFN 2004

\section{Taxation in the Petroleum Sector}

The importance of oil in world economy cannot be overemphasized. As was aptly captured by a notable scholar, ${ }^{27}$ the role of oil in world economy is a major feature of the second half of the20th century. It is both the most important source of energy and the largest internationally traded commodity.

The scale of capital involved in oil development and exploitation, the scope of the trade in oil, the size, the sophistication and complexity of the organization involved and the potential financial rewards make the industry unique.

The Federal Government of Nigeria as empowered (under the United Nations Resolution on Permanent Sovereignty over Natural Resources and the constitution, has passed laws aimed at controlling its resources, imposes tax, levies, royalties, bonuses and other diverse forms of tax in the Nigerian Petroleum industry.

The principal tax legislation in this sector is the Petroleum Profit Tax Act. Related laws are the Education Tax Act (ETA), Value Added Tax Act (VATA) Companies Income Tax (CITA) regime, and the Personal Income Tax Act (PITA) which regulates tax payable by employees in the oil industry. These aforementioned statutes shall be treated in details under taxation in the mining sector as they are not peculiar or limited to the petroleum sector.

27 Atseghua, L., Oil and Gas Law in Nigeria:Theory and Practice (Nigeria: New Era Publication, 2003) at p. 33. 
a) Petroleum Profit Tax Act Cap p 13 LFN 2004

The ambit of the Petroleum Profit Tax Act (PPT) was clearly stated in its preamble thus:

An Act to impose a tax upon profits from the winning of petroleum in Nigeria, to provide for the assessment and collection thereof and purposes connected therewith.

The Act further provides as follows:

"There shall be levied upon the profits of each accounting period of any company engaged in petroleum operation during that period, a tax to be charged, assessed and payable in accordance with the provisions of this Act."

The definition of "petroleum operation" received judicial pronouncement In the case of Shell Petroleum Development Company (Nig.) Ltd v. Federal Board of Inland Revenue ${ }^{28}$ where it was held by the Supreme Court that petroleum operation for the payment of profit tax by companies engaging in petroleum operations includes not only winning or obtaining petroleum oil by drilling, mining, etc., but all operations that are incidental to such operation.

The administration of petroleum profit tax is vested in the Federal Inland Revenue Service (formerly Federal Board Inland Revenue).

- Assessable Tax

The tax to be charged, assessed and payable in accordance with the provision of this Act. ${ }^{29}$ The assessable tax for any accounting period of a company shall be an amount equal to $85 \%$ of its charge able profit for that period. ${ }^{30}$ Simply put, this is tax levied on the profits of a company engaged in petroleum operations during an accounting period. The assessable tax rate of $65.75 \%$ is however chargeable for a company that has not commenced to make a sale or bulk disposal of chargeable oil under a programme of continuous production and sales. ${ }^{31}$

In order to ascertain the petroleum profit tax payable by a company under the Act for any accounting period, the computation of the following is necessary;

- Profits $^{32}$

28 (1996) 8 N. W. L. R (Pt. 466) 256; Section 2 of Petroleum Profit Tax Act Petroleum Operation is defined as the winning or obtaining and transportation of petroleum or chargeable oil in Nigeria by or on behalf of a company for its own account by any drilling, mining, extracting or other like operations or process, not including refining at a refinery, in the course of a business carried on by the company engaged in such operations, and all operations incidental thereto and any sale of or any disposal of chargeable oil or on behalf of the company."

29 Section 1 Petroleum Profit Tax Act Cap p13 LFN 2004.

30 Section 21(1) Petroleum Profit Tax Act Cap p13 LFN 2004.

31 Section 21(2) Petroleum Profit Tax Act Cap P13 LFN 2004.

32 Section 9(1) Petroleum Profit Tax Act Cap P13 LFN 2004. 
a. Proceeds of all chargeable oil sold by the company during that period,

b. Value of all chargeable oil disposed by the company during the period,

c. All income incidental to and arising from one or more petroleum, operations, e.g. interest on fixed deposit, rent/hire of equipment, income from services provided to another petroleum company, etc.

- Adjusted Profits

The adjusted profit of a company means the profit for that period after the deductions of expenses as contained in section 10(1), and any adjustments according to Section 14 of the Act. ${ }^{33}$ The deductions allowed under section 10(1) of the Act to be made before calculating its profit payable by it.

i. Rent incurred by the company;

ii. All non-productive rents, the liability of which was incurred by the company during that period;

iii. All royalties;

iv. Sums incurred by way of interest up money borrowed by the company;

v. Expenses incurred for repair of premises, plant, machinery or fixtures;

vi. Debts directly incurred by the company and proved to the satisfaction of the Board to have become bad or doubtful in the accounting period;

vii. Exploration and drilling costs, including costs relating to the drilling of the first two appraisal wells in a particular field; ${ }^{34}$

viii. All sum incurred by way of interest on any inter-company loans under terms prevailing in the open market;

ix. Any contribution to pension, provident or other society, scheme or fund as may be approved; etc., and all other deductions as may be prescribed by any rule made under the act.

The adjustments permitted according to Section 14 of the Act are provided thus;

"Where a company engaged in petroleum operation is engaged in the transportation of chargeable oil by ocean going oil-tankers operated by or on behalf of the company from Nigeria to another territory then such adjustments shall be made in computing an adjusted profit or loss as shall have the effect of excluding therefrom any profit or loss attributable to such transportation."

Beyond the scope of the provision of the Act with respect to adjustable profits, it was held by the Supreme Court in the case of Shell Petroleum Development Company (Nig.) Ltd V. F.B.I.R $R^{35}$ that scholarship expenses incurred by a company will qualify as allowable ex-

33 Section 9(3) petroleum profits Tax Act Cap P13 LFN 2004.

34 Lawal, K. T., Taxation of Petroleum Profit under the Nigeria's Petroleum Profit Tax Act, International Journal of Advanced Legal Studies and Governance, Vol. 4, No. 2, August 2013 https://ww w.icidr.org>Taxati...pdf April 4,2019, p. 9.

35 Supra. 
penses under section 10(1) of the Act. However, section 13 of the Act expressly stated the limitations of the profits to be deemed as adjustable, and which are summarized as follows;

i. Any disbursement or expenses not been money wholly and exclusively laid out or expended, or any liability not being a liability wholly or exclusively incurred, for the purpose of those operations;

ii. Any capital withdrawn or any sum employed or intended to be employed as capital;

iii. Any capital employed in improvement as distinct from repairs;

iv. Any sum recoverable under an insurance or contract of indemnity

v. Rental of or cost of repairs to any premises or part of premises not incurred for the purpose of those operations; etc.

- Assessable profit

The assessable profit of any company for any accounting period shall be the amount of the adjusted profit of that period after the deduction of -(a) The amount of any loss incurred by that company during any previous accounting period; and (b) the amount of any loss which under that section is deemed to be a loss incurred by that company in its trade or business during its first accounting period where applicable under the Act. ${ }^{36}$

- Chargeable profit

This is the amount of assessable profit after deduction of any amount allowed as capital allowance. ${ }^{37}$ Capital allowances are all those allowances due to the company under the Schedule of the Act, ${ }^{38}$ which in other words, Capital allowance is granted to a company engaged in petroleum operations in lieu of depreciation.

Every company engaged in petroleum operations shall not later than two (2) months after the commencement of each accounting period, submit to the authorities a return, the form of which the Board may prescribe, of its estimated tax for an accounting period. ${ }^{39}$ The estimated tax is to be paid in equal monthly instalments, ${ }^{40}$ of which the first monthly payment shall be due and payable not later than the third month of the accounting period. ${ }^{41}$ Each of the remainder monthly payments shall be due and payable not later than the last day of the month in question. ${ }^{42}$ If any instalment due and payable is not paid within the appropriate time limit, a sum equal to five (5) per cent of the amount due as installment shall be added to amount due. ${ }^{43}$ Any company disagreeing with the assess-

36 Section 16(1) Petroleum Profit Tax Act Cap p13 LFN 2004.

37 Ibid Section 20(1).

38 Ibid Section 16(1).

39 Ibid Section 33(1).

40 Ibid Section 45(1).

41 Ibid Section 45(2).

42 Ibid Section 45(3).

43 Ibid Section 46. 
ment served on it by the Board has a right of appeal to the Appeal Commissioners, in the manner prescribed under the Act. ${ }^{44}$

\section{Taxation and Tariff Revenue in the Mining Sector}

There are various types of taxes and tax revenues payable on mining of minerals in Nigeria ranging from corporate to personal taxes, the most important of which shall be briefly examined below;

\section{a. Royalty}

Royalty can be defined as 'a payment to an owner for the use of property, especially patents, copyrighted works, franchises or natural resources ${ }^{45}$ Royalty is payable on any mineral obtained in mining explorations or operations in Nigeria ${ }^{46}$. The Ministry of Mines and Steel Development approves all royalty regimes. The $\mathrm{Act}^{47}$ provides: "Any mineral obtained in the course of exploration or mining operations shall be liable to pay royalty as prescribed in the regulations made under this Act." The Minister may on his authority grant waivers or reduction if satisfied that same is being exported solely for scientific analysis or experiment or as specimen in a reasonable quantity. ${ }^{48} \mathrm{He}$ may also defer payment on royalty on any mineral for a specific period, subject to the approval of the Federal Executive Council. $^{49}$

\section{b. Annual Service Fee}

Holders of a mineral title, other than the holder of a reconnaissance permit, shall pay an annual service fee to the Mining Cadastre Office equal to the number of Cadastral Units that comprise the title area multiplied by the fee per Cadastral Unit for that type of title. This fee is payable on the anniversary of the issuance of the mining title. Holders of a small-scale mining lease, mining lease, quarry lease, or water use permit shall pay annual surface rent to the owner or occupier of the land, subject to the approval of the Minister. It is also subject to review by the Minister at intervals of five (5) years. ${ }^{50}$

44 Ibid Section 41.

45 www.investopedia.com/terms/r/royalty.asp.

46 Section 33(1) Nigerian Minerals and Mining Act 2007.

47 Ibid section 33(1).

48 Ibid Section 33(2).

49 Ibid Section 33(3).

50 Ibid section 102(1). 


\section{C) Companies Income Tax}

The Companies Income Tax is assessed under the Companies Income Tax Act (CITA $)^{51}$ which regulates the taxation of all limited liability companies in Nigeria. As such, Companies involved in mining activities are assessed to tax under the Companies Income Tax Act $(\mathrm{CITA})^{52}$, as amended. However, individuals and partnerships engaged in mining activities are liable to tax under the Personal Income Tax Act (PITA) ${ }^{53}$. The profit of a company engaged in mining activity is liable to Company Income Tax (CIT) at the rate of thirty per cent $(30 \%) .{ }^{54}$ The tax is applicable on the total profits of the company, after adjusting for non-tax-deductible items, unutilized losses from prior years and capital allowances (tax depreciation), if any. The CIT is payable to the Federal Inland Revenue Service (FIRS) ${ }^{55}$ If a mining company's turnover is below N1million within the first five years of commencement of business, it will be liable to tax at the rate of twenty per cent $(20 \%)$. However, this provision would not apply where such mining company is granted a pioneer status. ${ }^{56}$ Pioneer Status is a tax holiday granted to qualified (or eligible) industries anywhere in Nigeria and the grant is aimed at enabling such a company achieve significant capital expenditure and returns during its nascent years. The Companies Income Tax Act (CITA) provides that a new company going into the mining of solid minerals will be exempt from tax for the first three years of its operations. ${ }^{57}$

CITA stipulates that minimum tax is payable by any company under any of the following conditions: where in any year of assessment the ascertainment of total assessable profits from all sources of a company results in a loss, or where the tax payable is less than the minimum tax, The exceptions to this rule are:

1. Where a company is in its first four years of commencement of business.

2. where a company is engaged in agricultural trade or business, or

3 . where $25 \%$ or more of the company's equity capital is imported, typically evidenced by a Certificate of Capital Importation (COCI).

Therefore, where a mining company meets the above conditions, it would be exempted from the payment of minimum tax.

Where a company is engaged in a trade or business with any other person on a partnership basis, that trade or business shall be deemed to constitute a separate source of profits and assessable profit of the company from that source shall be determined under the provi-

512007 , Laws of the Federation, 2004 as updated to the $31^{\text {st }}$ of December 2010.

52 Ibid.

53 Ibid.

54 KPMG Advisory Services, 'Nigeria Mining Sector' (2012) http://www.ng.kpmg.com accessed on $4^{\text {th }}$ Nov. 2014, p. 9.

55 Ibid.

56 Ibid.

57 Ibid. section 36. 
sions of the Personal Income Tax Act in like manner as would be the assessable income of any individual partner in a partnership business.

d) Personal income Tax

An individual or partnership carrying on mining activities is liable to Personal Income Tax under the Personal Income Tax $\mathrm{Act}^{58}$ on any profit or gain from such activity in line with the provisions of PITA. PIT is payable to the Statese Boards of Internal Revenue (SBIRs) where the individual or the partner is resident. ${ }^{59}$ The incomes chargeable to tax under the PITA include gains or profits from any trade, business, profession or vocation, for whatever period of time such trade, business, profession or vocation may have been carried on or exercised. ${ }^{60}$

While mining companies are taxed under CITA, their staff that are taxed under PITA since all individuals of taxable age in Nigeria are taxed under PITA except military personnel and residents of the Federal Capital Territory which is payable to the Federal Inland Revenue Service. ${ }^{61}$ Section 1 of the Act imposes tax on the income of individuals, communities as well as families. The tax is payable by persons other than those covered under paragraph " $b$ " of section 2 thereof.

Where a partnership is formed for the purpose of carrying out and engaging in mining, any income derived by the partners will be taxed as income accruing to individuals. ${ }^{62}$ In this case the income of a partner is seen as an income accruing to an individual. The implication of this is that such an income will be liable to tax under the Personal Income Tax Act just like income accruing to individuals. ${ }^{63}$

The Act makes provisions for the payment of a minimum tax, payable on the turnover of the business of an individual or a partner in a partnership business, which shall be a fair and reasonable percentage of the turnover of the business if the whole of the operations of the business are carried on in Nigeria, as the relevant tax authority may determine. ${ }^{64}$

\section{e) Education Tax}

Companies engaged in mining activities are liable to pay education tax under the Education Tax Act. ${ }^{65}$ The Act provides as follows; as from the commencement of this Act, there shall

58 Cap P.8, Laws of the Federation of Nigeria, 2004, amended by Personal Income Tax Act (Amendment Act), Laws of the Federation of Nigeria, 2004 as updated to the $31^{\text {st }}$ of December,2010.

59 Dema, p.17.

60 Section 3(1) PITA.

61 Ibid Section 17.

62 Kamoru p.12.

63 Ibid p.12.

64 Section 7(1)(a) PITA.

65 Cap. E4, Laws of the Federation of Nigeria, 2004. 
be charged and payable an annual education tax which shall be assessed collected and administered in accordance with the provisions of this Act. ${ }^{66}$ This is payable within sixty days from the date of assessment. ${ }^{67}$

\section{f) Value Added Tax}

Value added tax is a tax imposed on the supply of goods and services. ${ }^{68}$ The Act exempts certain goods from taxation. Mineral title holders are expected to charge a Value-AddedTax at the rate of $5 \%$ on all minerals sold locally. ${ }^{69}$ The act requires manufacturers, wholesalers, etc., to register within six (6) months of commencement of business. ${ }^{70}$

VAT is not payable on minerals exported from Nigeria as such as it is zero-rated. ${ }^{71}$ The implication for a zero-rated item is that a refund of VAT input is due.89 VAT is administered by the Federal Inland Revenue Service through its VAT.

\section{g) Capital Gain Tax}

Capital Gain Tax is the tax you are mandated to pay on the profit you receive when you sell an asset or investment. Payment of capital gain tax in Nigeria is regulated by the provisions of Capital Gain Tax Act. ${ }^{72}$ The Capital Gains Tax Act is a tax compliance drawn up by the federal Inland Revenue Service. It is an act established for the taxation of capital gains accruing on disposal of assets. ${ }^{73}$

The applicable tax rate is currently $10 \%{ }^{74}$, and is levied on capital gains accruing to a company or individual on disposal of chargeable assets or interest, irrespective of whether the assets is situated in Nigeria or not. ${ }^{75}$ Capital gains accruing outside Nigeria to a nonresident company or individual are subject to tax only on the amount received or brought into the country. ${ }^{76}$

Section 11 of the Act gives a clear understanding of how this Capital gain is being computed for taxation. It is calculated as the difference between your capital proceeds and your "cost base", which is the initial amount paid for your capital gain asset, plus expenditure

66 Ibid. section 1(1).

67 Ibid. section 2(2).

68 www.lawpadi.com, last accessed on May 9, 2019.

69 Section 4 of the Value-Added Tax Act, Cap. V1, Laws of the Federation of Nigeria, 2004.

70 Ibid section 8 .

71 Ibid section 2 .

72 Capital Gains Tax Act, Laws of the Federation of Nigeria, 2007.

73 Abdul-Wahab Ibrahim; Tax Legislation, and overview of Capital Gains Tax Act, march 13, 2017, www.pml.com.ng/tax-legislation- last accessed on May 10, 2019.

74 Ibid. section 2(1).

75 Dema, p.18.

76 Ibid. section 4. 
incurred on acquiring, holding, and disposing the asset. ${ }^{77}$ In respect of mining business, capital gain tax is payable on the disposal of any of the mining assets or interest of a company or individuals engaging in mining activities. ${ }^{78}$

\section{h) Withholding Tax}

Withholding tax is the tax required by law to be withheld by a party from each payment made to a contracting party from the income or services it rendered. ${ }^{79}$ This tax is required to be remitted periodically to the Federal Government through its authorized agency. This tax was introduced in Nigeria to increase the efficiency of tax collection and prevent tax evasion. ${ }^{80}$ The primary collecting agent of the withholding tax is any organization or bodies making payments to suppliers of goods or services, before final remittal to the federal Government. Withholding tax is therefore nothing more than a machinery to curb tax evasion. ${ }^{81}$

The Court of Appeal in 7Up Bottling Co. Plc. v. L.S.I.R.B ${ }^{82}$ per Nzeako, JCA defines withholding tax as follows:

The way I understand it, is that the withholding tax system is a form of tax administration which enables tax authorities to recover at source from taxable persons tax from payment made from certain services which such person render to another. What is deducted by the person who pays for the service is a percentage of this payment. Now if so deducted, when the taxable person's tax for the year is duly assessed, whatever had been deducted is credited to him in a manner that he does not pay tax twice on the same income accruing from that payment.

In 2013 the Minister of Finance approved a new Withholding Tax ("WHT") Regulation for Nigeria. Under the new regulation dividends, interest, rent, royalty and other qualifying payments to shareholders, vendors and lenders are liable to WHT deduction at the appropriate rate. The rates vary between $5 \%$ and $10 \%$, depending on the nature of the transaction and whether the beneficiary of the payment is a natural person, partnership or a limited liability company. ${ }^{83}$ The WHT rate on dividend, interest, rent and royalty when the beneficiary is resident in a country with which Nigeria has a double tax agreement ("DTA") is $7.5 \%$,

77 Abdul-Wahab Ibrahim (supra).

78 Kamoru, p.14.

79 S. Olawale, Withholding Tax Rates in Nigeria: All You Need to Know www.naijaquest.com, last accessed on May 9,2019.

80 S. Olawale, supra.

81 Akintayo Eribake, Distinguishing withholding tax from value added tax, Vanguard Newspaper, December 23,2013, also accessible on www.vanguardngr.com.

82 [2000] 3 N.W.L.R (Pt. 650) 565 at p. 617, paras. G-H.

83 Dema, p.18. 
compared to $10 \%$ that is generally applicable on such payments. Withholding tax is also payable on royalties, hire equipment, motor vehicle, plant, etc. ${ }^{84}$

\section{i) Stamp Duties}

Stamp duties are taxes payable on all dutiable documents and transactions, or simply put, a tax payable on any agreement executed in Nigeria or relating, whatsoever, to any property situated in or to any matter done in Nigeria. ${ }^{85}$ Payment of stamp duties in Nigeria is governed by the Stamp Duties Act. ${ }^{86}$

Stamp duties are also payable on the initial authorized share capital of a company and on any subsequent increase of such shares, at the rate of $0.75 \%$. Thus, for a company engaging in mining of mineral resources, stamp duties are payable on the authorized share capital of such company, or on any document or transaction which involves a mining company, which falls under the ambit of the Stamp Duties Act. Stamp duties is only payable where there is a transfer of assets or shareholding interests from one company to another. All instruments that are required to be stamped under the Stamp Duties Act must be stamped within 40 days of first execution.

\section{Obstacles and Challenges in Collecting Taxes and Duties on Natural resources in Nigeria}

Inspite of the rich endowment of natural resources which Nigeria boasts, the sector, with the exclusion of Petroleum exploration, has not made significant contribution to the nation's Gross Domestic Product with respect to tax and revenue collection, owing to a number of factors. ${ }^{87}$ These factors have significantly affected the sector in a number of ways, particularly in the area of revenue generation. This is in-spite of various policy changes geared at a more effective, and efficient way of tax collection and administration. Some of the challenges include which has affected revenue generation in this sector includes:

\section{Illegal Mining}

The activities of illegal miners in Nigeria is a mammoth challenge which has plagued the mining sector, and is perhaps the most damaging to tax and revenue collection and generation. These illegal miners are often described as artisanal or informal miners. This in-turn significantly affects the amount of revenue government we could have been generating

84 By the combined effect of sections 78-81 of CITA, and the Withholding Tax Regulation.

85 www.taxsummaries.pwc.com/ID/Nigeria-Corporate-Other-taxes., last accessed on May 8, 2019.

86 Cap S8, Laws of the Federation of Nigeria, 2007.

87 Emma Ujah and Emmanuel Elebeke, \$32 Billion Japanese Grant: Nigerian Mining Sector Can Benefit http://www.vanguardngr.com/2013/06/32-billion-japanese-grant-nigerian-mining-sector-canbenefit-ekosin Accessed may 6, 2019. 
from the sector vide tax and royalties, and poses serious economic challenge to the sector. Illegal mining is a serious offence under the Mining Act. ${ }^{88}$ The challenge posed by the activities of illegal miners appears intractable in spite of the administration's effort to streamline their 'operations' by encouraging the formation of a co-operative society.

Alhaji Abubakar Bwari, the Minister for State, Ministry of mines, steel and Development reported that more than two million people in Nigeria depend on illegal mining for their livelihood. ${ }^{89}$ For instance, it is said that the country lost about $\$ 50$ billion (N8 trillion) through illegal mining and exportation of unprocessed gold to neighboring states in $2013 .{ }^{90}$ It has also been reported that there are at many illegal mining sites operating in Benue, Niger, and Zamfara States. ${ }^{91}$

The Nigeria Extractive Industry Transparency Initiative (NEITI) disclosed that the Chinese and Indian companies have been involved in illegal mining of Nigeria's solid mineral deposits across the country. ${ }^{92}$

\section{Inadequacy of Legal Framework For Mining And Petroleum Production Tax In Africa}

It cannot be over emphasized that the majority of the laws governing tax and revenue collection in Nigeria are obsolete and are long overdue for a total overhaul. While various administrations have made attempts at modernization of our tax laws, majority of our tax provisions still date back to the 70's and 80's, and lie awkwardly, and out of place in the $21^{\text {st }}$ century. There have not been enough, and frequent amendments to keep pace with global developments, and recent complex solid minerals and mining activities involved in by companies, including sale of assets, joint ventures, etc, so as to ensure an appropriate and commensurate monitoring of activities, and adequate taxation.

In Nigerian, there has been various relinquishments and transfer of onshore oil blocks by international oil companies to indigenous licensees. The question arises if Nigeria's Federal Inland Revenue Service (FIRS) was aware of all these transactions and did it asses these asset(s) transfers for the purpose of Capital Gains Tax (CGT) $?^{93}$

Similarly, several indigenous upstream petroleum production licensees have being benefiting from 'Pioneer Status' which is statutorily provided for companies involved in pure-

88 Section 131 of the Minerals and Mining Act, 2007.

89 Report at a two-day "First National Stakeholders' Discourse on Oportunities and challenges of Artisanal mining in Nigeria" in Abuja, Punch News of $6^{\text {th }}$ May,2019, accessible on www.punchng.co $\mathrm{m}$ /over-two-million-people-in-Nigeria-depend-on-illegal-mining-for-survival-ministry-reveals/am p, last accessed on May 9th, 2019.

90 Nnbaugwu, F, Nigeria Loses N8trn to Illegal Mining of Gold. Vanguard News of 28th February, 2013. Available at: http:/www.vanguard.com/2013/02/nigerian-loses-8trn-to-illegal-mining/. Accessed $9^{\text {th }}$ May, 2019.

91 Arga, S., www.m.news24.com/Nigeria/National/News/20-illegal-mining-activities-in-Benue-Mini stry-20130404. Accessed $9^{\text {th }}$ May, 2019.

92 Kamoru, p.20.

93 Dr. Perisuo Dema, supra. 
ly industrial processes. As a basis for continued waiving of tax obligations is there a legal provision compelling a government agency to monitor the operations of 'Pioneer Status' ${ }^{94}$ The existing fiscal framework for investors in the mining sector is also not friendly enough and does not consider the peculiar nature of the sector, particularly its gestation period. ${ }^{95}$ The lack of a robust framework for investors in the mining sector has led to the shying away of investors from the mining sector, which in turn has placed a limit on the amount of revenue that can be generated from this sector.

\section{Poor tax Administration}

Ministries, departments, and agencies suffer from limitations in manpower, tools, money and machineries to meet the ever increasing needs of taxpayers. Staff of these agencies are not regularly trained and kept abreast with global best practices and innovations in the tax world of administration. This makes assessment of tax very weak, and detrimental to the Federal Government, and the economy in general.

\section{Lack of specialized courts to handle tax matters}

While every state in Nigeria have specialized tax revenue courts, a lot of tax relate disputes end up at the regular superior courts. Most often than not, the presiding officers and judges have no special knowledge or expertise in tax laws, and as such no innovations or radical judicial activism have come the way of our tax laws. One major achievement attributed to the Federal Government is the reconstitution of the Tax Adjudication Tribunal, which was dissolved in 2016, across the six (6) geo-political zones. It is expected to foster speedy resolution of tax disputes.

\section{Conclusions and Recommendations}

The fiscal regime for the taxation of mineral resources is derived from the general tax law applicable to the country. Apart from petroleum that is specifically being governed by the provisions of the Petroleum Profit Tax Act, mining activities are essentially subject to the provisions of the Companies Income Tax Act and Personal Income Tax Act in addition to other legislations regulating companies' activities. There is, therefore, the need for the enactment of a specific tax law to adequately regulate the taxation of mineral resources in Nigeria.

In drawing the curtain, it is worthwhile to note a few innovations that have been brought into place by the Federal Government regarding tax regime generally in Nigeria.

94 Dema, ibid.

95 Key challenges facing the Nigerian mining sector, accessible on www.home.kpmg/ng/en/home/ins ights/2017/08/key-challenges-facing-the -nigerian-mining-sector.html, last accessed on May 5,2019 . 
For example, the Federal Government released the Income Tax (Country by country Reporting) Regulations, 2018, which gives effect to the Country-by-country Multilateral Competent Authority Agreement signed on 27 January 2016, and ratified on 3 August, 2016. ${ }^{96}$ The 2018 Regulations requires Multi-National Entities headquartered in Nigeria that meet the specified threshold of global revenue to provide tax authorities with information about their global activities, profits, and taxes. This will surely go a long way to improve tax transparency in the taxation of these entities. As such, Multi-National Enterprises involved in the mining of solid minerals and natural resources will be subject to the aforementioned regulation.

The Federal Inland Revenue Service also released the revised Income Tax (Transfer Pricing) Regulations 2018, which ushered in a new transfer pricing specific penalty. This Regulation introduces stiff penalties for Transfer Pricing offences. However, it is imperative for the legislature to pass a unified law which shall be the principal and operative law governing taxation of solid minerals and natural resources in Nigeria. This will review the current tax regime which is administratively complex to handle, avoid multiplicity of taxes, thereby putting in a place a more efficient tax collection system governing this important sectors. It will also make it easier to clamp down on corrupt tax practices. An apt example is that of Zambia changed its laws on mineral taxation in January 2015. Before the introduction of the 2015 tax regime, the tax system was said to be vulnerable to all forms of tax planning schemes such as transfer pricing, hedging and trading through "shell" companies which were not directly linked to the business. ${ }^{97}$ There were weak statutory provisions on 'capital allowances' and 'carry forward of losses' which eliminated potential taxable profits. Only two mining companies were paying CIT under the previous tax regime as most of them claimed that they were not in tax paying positions.

The Zambian Government thought it imperative to restructure the legal framework for mining tax by replacing the profit based tax system with a simple mineral royalty based regime that is final so that it insulates itself against tax planning schemes. It is unfortunate that Nigeria has only recently started taking taxation seriously when the Federal Inland Revenue Service and other Inland Revenue Services were granted autonomy. ${ }^{98}$ It is pleasing that the focus has now been shifted to the taxation of the non-oil sector in recent times though belatedly. ${ }^{99}$ Sustained action on taxation is the only way out to promote Nigerian

96 Olaleye Adebiyi, Joshua Bamfo, Ogochukwu Isiadinso Nigeria: Nigerian Tax \& Fiscal Outlook 2019, available on https://www.mondaq.com/Nigerian+Tax+FIscal+Outlook+2019. (last accessed on April 4, 2019).

97 Dr. Perisuo Dema, Taxation Of Natural Resources: Legal Framework Choices, presentation delivered at 1st Africa tax symposium by International Bureau for FISCAL documentation (IBFD) June 18-19, 2015 Zambesi Sun Hotel, Livingstone, Zambia, p. 13.

98 Prof Olateju Abiola Somorin Guest speaker at a Town and Gown seminar delivered on February 15,2018 at Covenant University available https://m.covenantuniversity.edu.ng/News/Taxation-Gur u-Canvasses-Reforms-in-Nigeria-s-Tax--system\#.XP7Te2lo-yU (last accessed on April 4,2019).

99 Supra. 
economy, and as such the Federal Government through its legislative, judicial and administrative organs must be proactive, and innovative in bringing the tax regime to par with international best practices, and standards or risk steady regression of the economy.

Finally, the reconstitution of the Tax Adjudication Tribunal, which was dissolved in 2016, across the six (6) geo-political zones, ${ }^{100}$ is a step in the right direction. The system must be comprehensively structured across not just geo-political zones, but at state levels, and staffed with taxation experts as presiding officers. It is also recommended that the legislature consider making them superior specialized courts of record. This will lead to a more efficient interpretation and implementation of tax laws, which will have a massive impact on our economy.

\section{BIBLIOGRAPHY}

\section{Articles in journals}

Prof. Richard Idubor, Prof Dominic Asada and Olong Matthew Adefi, Appraising taxation and the Nigerian Oil Industry, Journal of Law Policy and Globalization, Volume 37, 2015, 188 www.iiste.org April 4,2019

Lawal, K. T., Taxation of Petroleum Profit under the Nigeria's Petroleum Profit Tax Act, International Journal of Advanced Legal Studies and Governance, Vol. 4, No. 2, August 2013 https://www.icidr. org > Taxati...pdf April 4,2019

Dr. Perisuo Dema, Taxation Of Natural Resources: Legal Framework Choices, https://www.ibfd.org>p df accessed on April 4,2019

\section{Books}

Adam Smith, Wealth of Nations, (New York: 2003)

Atseghua, L., Oil and Gas Law in Nigeria. Theory and Practice (Nigeria: 2003)

Omorogbe, Y. Oil and Gas Law in Nigeria, (Lagos: 2001)

\section{Internet Sources}

Abdul-Wahab Ibrahim, Tax Legislation, and overview of Capital Gains Tax Act, march 13, 2017, www.pml.com.ng/tax-legislation- last accessed on May 10, 2019.

Akintayo Eribake, Distinguishing withholding tax from value added tax, Vanguard Newspaper, December 23, 2013, also accessible on www.vanguardngr.com last accessed on $10^{\text {th }}$ of May, 2019.

KPMG Advisory Services, 'Nigeria Mining Sector' (2012) http://www.ng.kpmg.com accessed on $4^{\text {th }}$ Nov. 2014

Key challenges facing the Nigerian mining sector www.home.kpmg/ng/en/home/insights/2017/08/keychallenges-facing-the -nigerian-mining-sector.html, last accessed on $5^{\text {th }}$ of May, 2019.

100 Olaleye Adebiyi, Joshua Bamfo, Ogochukwu Isiadinso, ibid. 
Lilian Hart, Issues and challenges with the Nigerian taxation system- Chemiron v LIRS revisited, https://proshareng.com/news> (last accessed 02/05/2019)

Emma Ujah and Emmanuel Elebeke, \$32 Billion Japanese Grant: Nigerian Mining Sector Can Benefit http://www.vanguardngr.com/2013/06/32-billion-japanese-grant-nigerian-mining-sector-can-benef it-ekosin Accessed may 6, 2019

Nnbaugwu, F, Nigeria Loses N8trn to Illegal Mining of Gold http://www.vanguard.com/2013/02/nigeri an-loses-8trn-to-illegal-mining/ Accessed $9^{\text {th }}$ May, 2019.

Olaleye Adebiyi, Joshua Bamfo, Ogochukwu Isiadinso Nigeria: Nigerian Tax \& Fiscal Outlook 2019, available on https://www.mondaq.com/Nigerian+Tax+FIscal+Outlook +2019 accessed on April 4, 2019

Covenant University, Taxation Guru Canvasses Reforms in Nigeria's Tax system https://m.covenantuni versity.edu.ng/News/Taxation-Guru-Canvasses-Reforms-in-Nigeria-s-Tax--system\#.XP7Te2lo-yU accessed on April 4,2019

Punch News, Over Two Million People in Nigeria Depend on Illegal Mining for Survival Ministry Reveals, www.punchng.com/over-two-million-people-in-Nigeria-depend-on-illegal-mining-for-survi val-ministry-reveals/amp accessed on May 9th, 2019.

Prof. Lar Uriah, Geology and Mineral Resources of Nigeria and Their Uses www.researchgate.net/pub lication/322963731_> accessed on 01/05/2019

S. Olawale, Withholding Tax Rates in Nigeria: All You Need to Know www.naijaquest.com, last accessed on May 9,2019.

\section{Legislations}

Constitution of the Federal Republic of Nigeria 1999 (as amended).

Capital Gains Tax Act

Personal Income Tax Act (Amendment Act), Laws of the Federation of Nigeria, 2011.

Petroleum Act, 1969, Laws of Federation of Nigeria 2004

Petroleum Profit Tax Act Cap p13 LFN 2004

Value Added Tax Act, Cap. V1, Laws of the Federation of Nigeria, 2004.

Minerals and Mining Act, 2007. 